\title{
Exposure Dose Description
}

National Cancer Institute

\section{Source}

National Cancer Institute. Exposure Dose Description. NCI Thesaurus. Code C83279.

A characterization of the dose of an exposure to something. 